\title{
Principal Components Analysis Utility in the Livestock Field
}

\author{
Ancuța Simona ROTARU ${ }^{1}$, Ioana POP ${ }^{2}$, Anamaria VATCA ${ }^{1}$ and Luisa ANDRONIE* \\ ${ }^{1}$ Faculty of Animal Science and Biotechnologies, University of Agricultural Sciences and Veterinary \\ Medicine, 3-5 Mănăştur Street, 400372 Cluj-Napoca, Romania \\ ${ }^{2}$ Faculty of Horticulture, University of Agricultural Sciences and Veterinary Medicine, 3-5 Mănăştur \\ Street, 400372 Cluj-Napoca, Romania \\ * corresponding author: luisa.andronie@usamvcluj.ro
}

Bulletin UASVM Animal Science and Biotechnologies 73(2)/ 2016

Print ISSN 1843-5262; Electronic ISSN 1843-536X

DOI:10.15835/buasvmcn-asb: 12231

\begin{abstract}
Principal Component Analysis is a method factor - factor analysis - and is used to reduce data complexity by replacingmassive data sets by smaller sets. It is also used to highlight the way in which the variables are correlated with eachother and to determining the (less)latent variableswhich are behind the (more)measured variables. These latent variables are called factors, hence the name of the methodi.e. factor analysis. Our paper shows the applicability of Principal Components Analysis (PCA) in livestock area of study by carrying out a researchon some physiological characteristics in the case of tencow breeds.By using PCA only two factors have been preserved, concentrating over $80 \%$ of their information from the four variables in question, one factor concentrating weight and height and the other factor concentrating trunk circumference and weight at calving, respectively.
\end{abstract}

Keywords: correlation matrix, factor analysis, main components

\section{INTRODUCTION}

Principal Components Analysis method first appeared in various psychological studies that attempted to assess variables such as intelligence, more exactly how one can evaluate characteristics such as power of assimilation, understanding, responsiveness, and one found that many of them are determined by a hidden variable i.e. intelligence (Helmy et.al, 2009).The initiator of Principal Components Analysis was Pearson and in 1933 this method was subsequently developed by Hotteling.

\section{AIMS AND OBJECTIVES}

The objective of this paper is to provide information about the Factor Analysis method which is method widely spread andused in various domains, such as livestock sector.

\section{MATERIALS AND METHODS}

Four physiological characteristics were considered in our analysis: height $(\mathrm{cm})$, weight $(\mathrm{kg})$, the trunk circumference $(\mathrm{cm})$ and weight of the calves at calving (kg) for ten breeds of cattle. For these ten breeds of cattle were considered average values for height, weight, trunk circumference and weight of calves at calving. The data are showed in Table 1 below.

The Principal Components Analysis method consists in the presence of a set of variables $\mathrm{X}_{1}$, $\mathrm{X}_{2}, \ldots, \mathrm{X}_{\mathrm{m}}$, and one aims to determine a new set of variables $F_{1}, F_{2}, \ldots, F_{n}$, also called factors or components, where $F_{i}=v_{i 1} X_{1}+v_{i 2} X_{2}+\ldots+v_{i m} X_{m}$, provided that $\mathrm{n}<\mathrm{m}$. Reversal is also required, that is the possibility to retrieve the variables $\mathrm{X}$ using components, i.e. $X_{i}=b_{i 1} F_{1}+b_{i 2} F_{2}+\ldots+b_{\text {in }} F_{n}$. Thus one may notice that via components one attempts to reduce the number of variables, without losing the original variables variance.

\section{RESULTS AND DISCUSSION}

Our paper uses Principal Components Analysis technique using SPSS. KMO (Kaiser-Meyer-Olkin) is a statistic test that indicates the degree of 
Tab. 1.Physiological characteristics in the case of ten cattle breeds

\begin{tabular}{ccccc}
\hline & \multicolumn{4}{c}{ Physiological Characteristics } \\
\cline { 2 - 5 } Breed Cows & Height $(\mathrm{cm})$ & Weight $(\mathrm{kg})$ & Trunkcircumference $(\mathrm{cm})$ Weight calves at calving (kg) \\
\hline Romanian Spotted Cow & 133 & 600 & 186 & 39 \\
\hline Jersey & 130 & 400 & 130 & 25 \\
\hline Fleckviel & 150 & 750 & 145 & 30 \\
\hline Brown Cow & 123 & 450 & 127 & 45 \\
\hline Piemontese & 128 & 570 & 150 & 40 \\
\hline Holstein & 140 & 650 & 160 & 35 \\
\hline Simmental & 138 & 700 & 140 & 30 \\
\hline Red Steppe Cow & 133 & 525 & 145 & 32 \\
\hline Estonian Red Cow & 130 & 530 & 140 &
\end{tabular}

Tab. 2.Total Variance Explained

\begin{tabular}{|c|c|c|c|c|c|c|c|c|c|}
\hline \multirow{2}{*}{ Component } & \multicolumn{3}{|c|}{ Initial Eigenvalues } & \multicolumn{6}{|c|}{$\begin{array}{c}\text { Extraction Sums of Squared Rotation Sums of Squared } \\
\text { Loadings } \\
\text { Loadings }\end{array}$} \\
\hline & Total & $\begin{array}{c}\% \text { of } \\
\text { Variance }\end{array}$ & $\begin{array}{c}\text { Cumulativ } \\
\%\end{array}$ & Total & $\begin{array}{c}\% \text { of } \\
\text { Variance }\end{array}$ & $\begin{array}{l}\text { Cumulative } \\
\%\end{array}$ & Total & $\begin{array}{c}\% \text { of } \\
\text { Variance }\end{array}$ & $\begin{array}{c}\text { Cumulative } \\
\%\end{array}$ \\
\hline 1 & 2.304 & $\mathbf{5 7 . 6 0 3}$ & 57.603 & 2.304 & 57.603 & 57.603 & 1.754 & 43.842 & 43.842 \\
\hline 2 & 1.135 & 28.373 & 85.976 & 1.135 & 28.373 & 85.976 & 1.685 & 42.134 & 85.976 \\
\hline 3 & .482 & 12.038 & 98.013 & & & & & & \\
\hline 4 & .079 & 1.987 & 100.000 & & & & & & \\
\hline
\end{tabular}

Tab. 3. Rotated Component Matrix ${ }^{a}$

\begin{tabular}{ccc}
\hline & \multicolumn{2}{c}{ Component } \\
\cline { 2 - 3 } & 1 & 2 \\
\hline Height & .985 & -.019 \\
\hline Weight & .852 & .448 \\
\hline Trunk_circumference & .238 & .805 \\
\hline $\begin{array}{c}\text { Weight_calves_at_ } \\
\text { calving }\end{array}$ & .031 & .915 \\
$\begin{array}{c}\text { Extraction Method:Principal Component Analysis. } \\
\text { Rotation Method: Varimax with Kaiser Normalization. }\end{array}$
\end{tabular}

association of the variables. In our case, KMO test is 0.436 . This value is an argument favorable to the existence of factors, suggesting that factoring is appropriate.

From Table 2 below one concludes how much of the total variance is explained by retaining the two components as follows: if one accepts only one component $57.60 \%$ of the data total variance

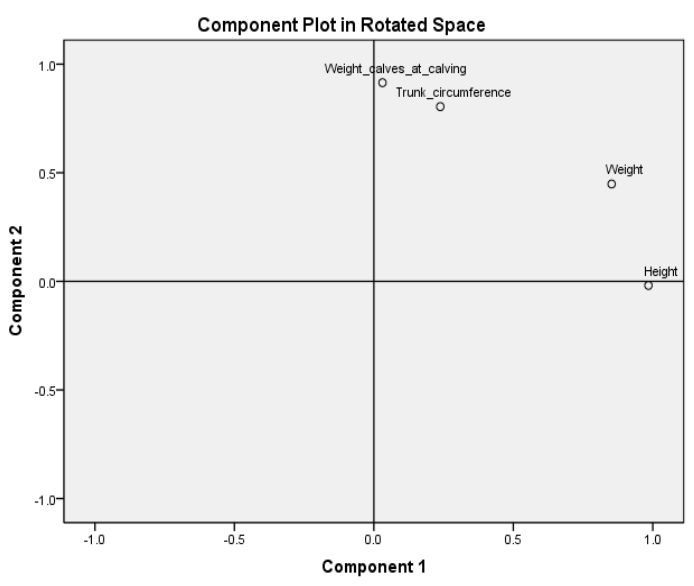

is explained; by accepting two components one recovers and additional $28.37 \%$ of the data total variance, therefore a total of $85.97 \%$ is a very good result for this analysis.

For a better understanding of data their rotation was required using Varimax method that minimizes the number of variables with high loadings on each factor. Loading matrix 
was displayed after rotation and in this case the differences in terms of load factors are highlighted better. A latent variable factor should bear a name in order to be understood. Loading structure of a factor can provide suggestions in this regard, namely loadings $>0.6$ are considered to be important and those $<0.4$ are low (see Table 3 ).

In the chart on the left one may notice the distribution of variables by the two components, namely:

- Factor 1 is well correlated with weight and height;

- Factor 2 is strongly correlated with trunk circumference and with the weight of calves at calving.

\section{CONCLUSION}

This paper is conceived to provide a theoretical section for the factor analysis method and a practical application there of in the livestock sector, by reducing data size, by using four variables i.e. weight, height, circumference of the trunk and weight of the calves at calving for ten cattle breeds. By using PCA only two factors have been preserved, concentrating over $80 \%$ of their information from the four variables in question, one factor concentrating weight and height and the other factor concentrating trunk circumference and weight at calving, respectively.

\section{REFERENCES}

1. Helmy, AK, E. I - Taweel ,GHS (2009). Authentication Scheme Based on Principal Component Analysis for Satellite Images, International Journal of Signal Processing, ImageProcessing and Pattern Recognition, Vol. 2, No.3, 2009, pp.5-14.

2. Ioniță I, Schiopu D (2010). Using Principal Component Analysis in Loan Granting, BuletinulUniversității PetrolGaze din Ploieşti, Vol LXII, No 1.2010, SeriaMatematicăInformatică-Fizică.

3. El - Bakry HM (2007). New Fast Principal Component Analysis for Face Detection, Journal ofAdvanced Computational Intelligence and Intelligent Informatics, Vol.11, No.2, 2007, pp.180-200. 